\title{
Why the Flapper Still Matters: Feminist Pedagogy, the Modern Girl, and the Women Artists of the Beaver Hall Group
}

\author{
Christina Ann Burr
}

University of Windsor

\section{ABSTRACT}

The flapper of the 1920s, with her bobbed hair, use of makeup, flashy dress, independent, flamboyant behaviour and eroticism, and love of dancing and jazz music, signified a new form of femininity, one where women were simultaneously modern objects and subjects. This article examines the flapper as a historical, historiographical, and pedagogical problem and addresses the question of why the flapper matters historically and why she should continue to matter to university teachers and researchers. The article dissects the learning experiences of a group of students who toured the 2016 exhibition of the modern art of Montreal's Beaver Hall Group in conjunction with a fourth-year seminar on the Modern Girl. Students explored a new and diverse visual economy based on a strong, independent, and assertive Canadian feminine modernity, and discovered that images of women could be empowering. I argue that the flapper challenges masculine traditions by encouraging historians to consider changeable feminine bodies and identities, thus breaking down longstanding binaries in Canadian history and historical writing. The flapper points to the use of the historical material in the everyday world. This confluence of women's history and visual culture suggests why the flapper still matters today.

\section{RÉSUMÉ}

La garçonne des années 1920, avec ses cheveux coupés au carré, son maquillage, ses robes clinquantes, son comportement indépendant et flamboyant, son érotisme, de même que son amour pour la danse et la musique jazz, a introduit une nouvelle forme de féminité où les femmes étaient à la fois des objets et des sujets modernes. Cet article examine la garçonne comme un phénomène historique, historiographique et pédagogique. Il s'interroge sur la signification historique de la garçonne et les raisons pour lesquelles elle devrait continuer d'intéresser les professeurs et les chercheurs universitaires. L'article décortique les expériences d'apprentissage d'un groupe d'étudiants qui ont visité l'exposition d'art moderne du Beaver Hall Group de Montréal en 2016, dans le cadre d'un séminaire de quatrième année sur la Fille Moderne. Les étudiants ont exploré une économie visuelle nouvelle et diversifiée basée sur une modernité féminine canadienne forte, indépendante et affirmée, et ont découvert que des images de femmes peuvent être empowering. Je soutiens que la garçonne défie les traditions masculines en encourageant les historiens à considérer des corps et des identités féminines variables, rompant ainsi des binarités établies de longue date dans l'histoire canadienne et 
l'écriture historique. La garçonne met en valeur l'utilisation de matériel historique dans le quotidien. Cette convergence entre l'histoire des femmes et la culture visuelle indique pourquoi la garçonne demeure pertinente aujourd'hui.

\section{Introduction: The Modern Girl and the Beaver Hall Group of Artists as a Historical, Historiographical, and Pedagogical Problem}

In the 2011 winter semester, I launched a new fourth-year history seminar on the Modern Girl at the University of Windsor. With her bobbed hair, use of makeup, flashy dress, brash and flamboyant behaviour, love of dancing and jazz music, her eroticism and longing for romance, the Modern Girl provided a segue for teaching visual culture and critical media literacy to upper-level undergraduate students who were, and still are, exposed predominantly to a narrative of Canadian history as the canon of great men uncovered through official state documents housed in public archives. The flapper is by and large presented as an invalid historical subject or else relegated to the dustbin of history to negative effect as a problem girl. In teaching the course over the last several years, I discovered that the flapper as a historical problem provides students with an opportunity to think critically about women's history through visual culture. Instead of thinking of the flapper as the problem girl of the 1920s and unworthy of consideration in the canon of Canadian historical writing, the flapper should be reconsidered as an important historical, historiographical, and pedagogical problem that can be used in the classroom, and in historical writing, to think critically about meaningful social change. Contrary to the traditions of the profession where history and historiography are not usually studied alongside pedagogy, I suggest that these three dimensions of the historical profession must be considered as interconnected, rather than teased apart into separate categories.

The Modern Girl emerged around the world during the years between the two world wars. (Throughout this paper, I use the terms Modern Girl and flapper synonymously.) She was distinguished by her appearance and symbolized the emergence of a new type of femininity that was seen as both popular and problematic. She was independent, intelligent, athletic, socially active, young, an urban dweller, and she appeared to disregard the traditional role of dutiful daughter. She was associated with a number of cultural types, including the movie starlet and her admirers, the star-struck girl, the business girl, the fashion model, the city girl, the flapper, the beauty contestant, the chorus girl, the bathing beauty, and others. Of all the types of Modern Girl, the flapper was perhaps the most spectacular in the visually intensified scene of modernity, notable for her appearance and for her consumption of an array of Modern Girl commodities, including cosmetics, mass-market fashions, cars, and cigarettes, and for constructing herself as a sexual subject in her quest for sexual objectification. ${ }^{1}$

Caught up in the post-war expansion of consumer culture and a new emphasis on women's bodies, the Modern Girl can be distinguished from her predecessor, the progressive, college-educated, middle-class New Woman of the turn of the twentieth century. The New Woman has been described by some women's historians as 
the mother of the Modern Girl. Contemporaries associated the New Woman with the middle class, a college education, a focus on securing work in "male" professions, social reform and political activism, and a rejection of traditional marriage. In the 1910s, the New Woman mobilized around the campaign for suffrage, although political differences among women occurred. By the 1920s, modern womanhood was associated with an urban industrial economy of mass production and mass consumerism. Nevertheless, hard and fast distinctions are not entirely useful; there were New Women who were avid consumers and Modern Girls who engaged in various political projects. ${ }^{2}$

In developing my argument that the Modern Girl/flapper must be approached from multiple angles as a historical, historiographical, and pedagogical problem, I begin by discussing pedagogy and how my undergraduate course on the Modern Girl has evolved since I first began teaching it in 2011, and how I was influenced by the interdisciplinary group of scholars involved in the Modern Girl Around the World Research Group. During the fall 2016 semester, I had the opportunity to use the art and artists of the Beaver Hall Group to reconsider the Canadian flapper as a historical and historiographical problem and as a means to engage students in women's history and visual culture by incorporating a tour of an exhibition of their works at the Art Gallery of Windsor into the class. Montreal's Beaver Hall Group, which existed for only a short period of time between 1920 and 1922, was comprised almost equally of women and men. As women artists, they were real flappers, and they offered representations of feminine modernities in their art. The women of the Beaver Hall Group challenge the models of patriarchy in the writing of Canadian art history, which have largely been constructed around the masculinist view of Canadian national identity evident in the art of the Group of Seven. In the second section of the paper, I engage with Canadian art history and examine how the women of the Beaver Hall Group embodied the Modern Girl and how she was represented in their art. Here I suggest that the Beaver Hall Group used the flapper not only as a symbol of modernity, but as historical subjects themselves, the women of the Beaver Hall group were embodiments of the Modern Girl of the interwar period and have been viewed this way more recently by feminist art historians. The third section of the paper is a self-reflection on my efforts to engage a class of fourth-year history students in visual culture through a consideration of the Modern Girl in Canadian history and historiography using a class tour of an exhibition of the art of the Beaver Hall Group.

\section{Introducing the Modern Girl to University Students}

When I introduced the course in 2011, my intent was to use the Modern Girl, and her complex relationship with her predecessor, the New Woman, to explore how gender and sexuality have been constructed historically through visual culture and to expose students to various media sources for historical research, while retaining a historian's commitment to the craft of writing. I shared with my colleagues in the history department a concern that students were spending less time reading and were less able and willing to communicate their ideas in the written form; a concern that 
persists and has been compounded by students spending more of their time at paid employment. I hoped that students' experience with the flapper using visual culture and experiential learning opportunities would help them to engage with the material in a way that was more relevant to them and elevate their desire to communicate their ideas in writing.

In putting the course together, I was influenced by the research of the Modern Girl Around the World Research Group based at the University of Washington. This interdisciplinary research project was undertaken by scholars trained in literary criticism, history, cultural and feminist studies, and political economy, in focussed geographical spaces around the world. They found the nearly simultaneous emergence of the Modern Girl in urban areas and in colonial encounters globally during the two decades between the world wars. The term "Modern Girl" was used as a heuristic device to uncover how women were represented as modern objects who also represented themselves as subjects through their explicit eroticism and consumption of a particular bundle of commodities - cosmetics, personal care products like toothpaste and deodorant, hair-styling products, cigarettes, and fashionable, sexy clothing. As the Modern Girl Around the World Research Group states, "new commodities associated modernity, novelty, and self-care with consciousness of bodily autonomy, freedom, and sexual desire." 3 These discussions about the body and consumption, furthermore, cannot be separated from those about nationalism and nation-building and racial and class inequalities. ${ }^{4}$ Using these ideas, I was able to think critically about the flapper as a historical, historiographical, and pedagogical problem that might be used to make meaningful change in students' experiential learning opportunities, and as a topic in history for challenging how history is approached.

As a feminist whose training as a professional historian is in the area of Canadian social history, I have throughout my more than twenty-year teaching career embraced a feminist pedagogical practice that encourages students to challenge the traditional masculine narratives of academic historical writing. I have sought to bring experiential learning into the classroom, cultivate a relationship with students that respects and values the diversity and experiences of all students, and, in an increasingly visual world, offer history students tools for engaging with images and cultural issues, both historical and contemporary. ${ }^{5}$ Self-reflexivity in both learning and research practices also characterizes my feminist pedagogical practice and scholarship. I believe that to be most effective research and teaching should be carried out in conjunction with one another in a symbiotic relationship.

In looking back at the early course syllabi, I recall encouraging students to think about the representations, both textual and visual, of the Modern Girl and the role that representations of femininity played in defining modernity. I brought into the classes a variety of texts, including women's magazine advertisements, advice literature, fiction, and film clips, to encourage students to develop and extend their own critical thinking around the history of the body, and to understand further where ideas about gender and sexuality, many of which have become normative, come from. I also encouraged students to think about how the Modern Girls of the interwar period represented themselves as subjects through their consumption practices and 
eroticism. I attempted to open up space for the discussion of the Modern Girl with attention to gender, sex, ethnicity, and nationalism, drawing on the research of the members of the Modern Girl Around the World Research Group and others. I used readings from various geographical locations, particularly the US, where the literature was more developed in the area. Frustratingly, I found the literature on the Canadian modern woman was rather limited, with the exception of the important groundbreaking research by Veronica Strong Boag, which challenged the idea of the interwar period as a "new day" for women with suffrage won, and Carolyn Strange's study of young working women in Toronto between 1880 and 1930, although Strange's study largely focussed on the perils of the city for the working girl of the period. ${ }^{6}$ The dearth of Canadian writing on the Modern Girl has since been remedied with the publication of the edited collection of essays by Cheryl Karsnick Warsh and Dan Malleck, Tamara Myers' research on how the Quebec justice system curbed modern attitudes among adolescent girls between 1869 and 1945, and Jane Nicholas's major study of the Modern Girl, which picks up many of the threads of analysis of the Modern Girl Around the World Research Group. ${ }^{7}$ These works have been used in the course recently. Students have been eager to engage with visual images and have consistently made comparisons between the use of makeup by the Modern Girl to create the flapper look alongside the consumption of cosmetics by women in the present and their creation of the feminine self. Any resistance I encountered from students stemmed from the weekly reading requirements and the short written critical analyses of the readings they were required to submit. I have since eliminated this component of the course, but students are still required to engage in a critical discussion of the reading as part of their participation grade and write a final critical research paper using some primary source materials.

I offered the course at the graduate level in the winter 2016 semester. Historian Jane Nicholas delivered a public lecture at the university entitled "Why the Flapper Matters," which the students were required to attend. Nicholas expertly linked the flapper as a heuristic device with Canadian history and historical writing for the students. She suggested that the old, but still dominant, nationalist narrative in Canadian history briefly recognizes the flapper, but continues to treat her as an insignificant blip along the way. The Modern Girl is still considered something of a historiographical whore in Canadian historical writing: superficial, based in the body and her eroticism. ${ }^{8}$ In fact, as Nicholas explained, drawing on a considerable array of print advertisements from Canadian magazines and popular discussions on topics ranging from contemporary youth to art and beauty, historians just can't get away from the flapper. During the interwar period, Canadians self-consciously evaluated themselves as a nation and as modern citizens. Concerns over everything from contemporary art to cars to changes in important visual cues on race, class, and gender were encapsulated in discussions of the Modern Girl in Canada. In many ways the flapper was a powerful media representation, but she was one that was intimately connected to women's lives as modern women in Canada and an important historical subject in her own right.

Drawing on Bonnie G. Smith's The Gender of History: Men, Women, and Historical 
Practice and the writing of Carolyn Steedman, Nicholas stated that the flapper matters not only historically but she also matters to the writing of history. The suppression of female histories and historians has been deliberate in the shaping of modern historiography as white, male, masculine, and middle class. Even more telling is that historians have claimed Clio as their muse. Clio, as a muse, has been badly abused by historians allegedly defending her territory. But, as Carolyn Steedman argues, Clio doesn't care. Clio turns her blank face to all of her followers: whoever is there, it is still the same old story. ${ }^{9}$

In many ways the flapper might be considered a trope for Clio; not only doesn't she care, but like the modern single girl in the city in the 1920s, the department store mannequin in the visual economy of consumer capitalism, or the "blank-faced woman" in advertisements, Clio as a flapper exudes unlimited new possibilities for women's historians. She allows us to study changeable feminine bodies and identities and break down longstanding oppositions in historiography, particularly the longstanding binary in historical writing between the public and private spheres. She allows for a consideration of feminine visibility while breaking down long-standing oppositions between subject and object. ${ }^{10}$ In short, flapper Clio undercuts the assumptions of scientific history and the traditional narrative of nation-building history in Canada and produces what Steedman describes as "an altered sense of historical meaning and importance of female insignificance." The tale she tells will always be something "other": "a category that changes in different historical circumstances."11 The flapper continues to matter to historians, therefore, not because she was not cut off from the social world but because she allows us to use historical material in the everyday world.

Around the same time Jane Nicholas delivered her talk at the university, I noticed that social media had become much more pervasive in students' lives than it had been when I first offered the course in 2011. Students bring social media and its influences to class regularly, and I have encouraged this, but I also share the concerns of some critics of social media. For instance, in a review essay published in the New York Review of Books, British novelist and journalist Zoe Heller states that while on the surface American girls may appear to be the most privileged and successful girls in the world "thanks to the many hours they spend each day in an online culture that treats them - and teaches them to treat themselves - as sexual objects, they are no more, and perhaps rather less, 'empowered' in their personal lives than their mothers were thirty years ago."12 I searched for ways to bring the confluence of women's history, visual literacy, and students' participation in the online world to the classroom to educate critically engaged and empowered and responsible citizens capable of transforming our world. Also, how might I bring the idea that "the flapper still matters," both historically and historiographically, to the classroom? Like many of my feminist colleagues, I was concerned that in doing this I was somehow bucking the trend of an academic system that encourages students to "demonstrate knowledge" through the consumption of lectures, the memorization of these materials, and their regurgitation in exams, and that continues to view the university as "a privileged and protected fortress, distanced from the mundane preoccupations of everyday life."13 
As I prepared for the 2016 fall semester, I searched for ways to introduce students to the Modern Girl. Keeping in mind my belief in the interconnectedness of pedagogy, history, and historiography for studying the flapper, I laid out a few objectives for the course: (1) to challenge traditional thinking about Canadian history and search for ways to put social inequality and difference at the centre of history teaching and historical analysis; (2) to consider the flapper as an important subject in her own right in Canadian history and to use the Modern Girl as a way of challenging how we think about what history is; (3) to engage students in visual culture and ways of seeing the Modern Girl of the interwar period that uses insights into the history of the body and critiques the sexualization of women's bodies; (4) to encourage active citizenship among students in the community and beyond, including on social media; (5) and to consider the significance of women's friendships and networking to women's activism and professional networks.

One midsummer morning, I noticed an advertisement for the touring exhibition 1920s Modernism in Montreal: The Beaver Hall Group. The opening paragraphs of the advertisement caught my attention:

The Beaver Hall Group, although initially considered to be a Montreal counterpart to Toronto's Group of Seven, stood apart through their work. Rather than offering an image of Canadian identity through the depictions of the untamed landscapes of the northern country, the Montreal artists imbued the inhabited landscapes of northern culture with the colours of modernity.

They also painted many portraits that convey this same quest for modernism; these works rank among the most remarkable in the history of Canadian art. The male-female parity within the group - a first in Quebec as well as in Canada - is another resolutely modern trait.

The exhibition offered the potential to engage students in Canadian women's history, representation, and visual culture, to consider the flapper as an important historical subject in her own right, and to examine the art and the artists of the Beaver Hall Group alongside the research of the Modern Girl Around the World Research Group.

\section{Bringing the Beaver Hall Group and the Modern Girl into the History and Historiography of Canadian Modern Art}

As a Canadian social historian, although not an art historian by training, I was aware of the established canon surrounding the Group of Seven, who marketed a vision of Canada through their modernist landscape paintings depicting the wilderness of the Canadian North while rendering invisible the gender, racial, sexual, and body politics underlying this national myth. The exclusively male membership of the Group of Seven normalized our vision of a masculine Canadian national identity with what Brenda Lafleur describes as a "fixity on the land"; their painting of the Canadian landscape was codified through the elision of nationhood and masculinity with 
modernism in wilderness painting that emphasized the barren, rugged North. ${ }^{14}$ This underpopulated rural wilderness aesthetic as the expression of Canadian identity was given a boost in 2016 when American actor and comedian Steve Martin co-curated the exhibition, The Idea of the North: The Paintings of Lawren Harris at the Hammer Museum in Los Angeles and the Art Gallery of Ontario. ${ }^{15}$ The exhibition appeared in Toronto in July 2016, overlapping with the touring exhibition of the works of the Beaver Hall Group.

The Montreal Museum of Fine Arts exhibition, 1920s Modernism in Montreal: The Beaver Hall Group, which opened in Montreal in 2015 before travelling to Hamilton, Windsor, and Calgary, presented a timely historical statement about the relevance of the flapper and an important counter-argument to models of patriarchy in Canadian art history. Although viewed by some art historians as Montreal's counterpart to the Group of Seven, artists of both sexes worked, socialized, or exhibited with Montreal's Beaver Hall Group, which had only a short existence between 1920 and 1922. They challenged the Group of Seven's focus on wilderness as constitutive of national identity and instead unravelled the threads of modern life. The membership of the group fluctuated over the brief period of the group's existence, but the gender diversity of the group, and the support the women received from their male peers, was unique in professional art circles of the time. The Beaver Hall Group has received less recognition from Canadian historians than the renowned Group of Seven, although it played an important role in shaping Canadian modern art, feminine modernity, and the visual culture of the Modern Girl of the 1920s.

In the 1960s, alongside the resurgence of the contemporary women's movement, feminist art historians began recovering the work of women artists who had disappeared from the narrative of Canadian art history. The exhibition Canadian Fine Crafts, curated by Norah McCullough, which opened in 1966 to coincide with Canada's centennial celebrations, exposed the talent of Quebec's women artists. ${ }^{16}$ From this exhibition, the perception emerged that the Beaver Hall Group was largely composed of women, although there was a slight male majority. The actual composition of the group's female membership, however, was loosely defined, and was based on networks of women's friendships and the support of their male colleagues - the latter an anomaly for professional women of the time. Other exhibitions and publications by Barbara Meadowcroft and Evelyn Walters as well as a documentary film by Pepita Ferrari have since expanded our knowledge of the group's women. ${ }^{17}$

The most recent exhibition of the art of the Beaver Hall Group produced and toured by the Montreal Museum of Fine Arts (MMFA) was nearly ten years in the making. It was originally slated for 1979 and planned by feminist art historian Nathalie Bondil, director and chief curator of the MMFA; a position she occupies to date. ${ }^{18}$ The 2015-16 exhibit, co-curated by two men, Jacques Des Rochers and Brian Foss, was a post-feminist perspective on the Beaver Hall Group that restored men to the group's history with its emphasis on how the male members of the group actively supported their female colleagues. This doesn't mean, however, that this revisionist perspective robs "the women of their talent and fearlessness." The Beaver Hall women, Nathalie Bondil writes, "asserted their individuality with 
determination, talent and commitment... far from the stereotypes of young ladies from good families dabbling with a brush."19 Bondil's statement is consistent with the interpretation of Modern Girls as autonomous historical actors who challenged public/private divides and exercised new modes of agency available for women in the interwar period. ${ }^{20}$

Ten women-Nora Collyer (1898-1979), Emily Coonan (1885-1971), Prudence Heward (1896-1947), Mabel Lockerby (1882-1976), Henrietta Mabel May (1877-1971), Kathleen Morris (1893-1986), Lilias Torrance Newton (18961980), Sarah Robertson (1891-1948), Anne Savage (1896-1971), and Ethel Seath (1879-1963) — were associated either formally or informally with the Beaver Hall Group, and in recent years, they have received attention from feminist art historians. There were likely other women with connections to the group, either through personal relationships, art school classes, or shared studio space, or who exhibited alongside those who formally belonged to the group. The women, with a couple of exceptions, were from Montreal's English Protestant middle class, and many of them generated an income through the sale of their art or by teaching art classes. Emily Coonan was from an Irish Catholic immigrant working-class family. To date only one francophone artist, Jeanne de Crèvecoeur, who also worked as an occupational therapist, is known to have belonged to the group, although more research and recovery of the works of the group's female members is certainly needed. ${ }^{21}$ All of the women in the group were single with the exception of Lilias Torrance Newton, who divorced in 1933. The privileged social and economic position of the women allowed them to defy expectations of marriage and child-bearing and devote their lives to their careers, although some of the women had economic and familial constraints and responsibilities. Ethel Seath, the daughter of divorced parents, worked outside the home as a newspaper illustrator to pay for her art classes at the Art Association of Montreal, where all of the Beaver Hall women studied at some point between 1902 and 1924. In this transitional era, Prudence Heward combined the traditional role of dutiful daughter caring for her elderly mother with that of the modern woman who toured Europe exposing herself to new trends in modern art. Heward also took advantage of the new opportunities for women during the interwar period to exhibit their art in public and commercial galleries. ${ }^{22}$

In 1920s Modernism in Montreal: The Beaver Hall Group, a catalogue and collection of essays published in conjunction with the exhibition, Canadian art historian Kristina Huneault states that the social markers that distinguished the early twentieth-century feminist ideal of the "New Woman" were evident among the women artists in the group. She writes,

The group's female members variously bobbed their hair, drove automobiles and smoked. Most of them remained unmarried, and some explored options for companionship outside of matrimony. Some members joined women's rights organizations. Most importantly, the vast majority of the women carved out careers for themselves, as artists, art educators and illustrators. ${ }^{23}$ 
Huneault's remarks suggest that historians should heed the Modern Girl Around the World Research Group's warning against making hard and fast distinctions between the "New Woman" and the "Modern Girl." The women of the Beaver Hall Group engaged in the culture of consumption and took on the Modern Girl style with their bobbed hair and cigarette-smoking. Some explored new sexual options, while others embraced the characteristics of the "New Woman" with their political activism and professional ambitions. ${ }^{24}$

The Beaver Hall women met at the Art Association of Montreal School where they formed a network of lifelong friendships and struggled to carve out careers as professional artists in the male art world. As Barbara Meadowcroft argues, this friendship network, a strategy of support traditionally used by women in the private sphere of the home, provided not only support in the form of intimacy but professional support in the form of critical commentary, travel companions, and strategies for navigating the male-dominated art world to which they sought acceptance. Most early twentieth-century male artists viewed women's art as amateurish and merely a pastime of middle-class women in the domestic sphere. The women artists of the Beaver Hall Group demonstrate why the flapper continues to matter to women's historians by complicating and breaking down the long-established gender binary of private and public in Canadian historiography with their new public display of feminine modernities. ${ }^{25}$

The Beaver Hall Group was eclectic and came together for exhibitions and social gatherings. Unlike the Group of Seven, the Beaver Hall women, with the exception of Anne Savage, who shared A. Y. Jackson's enthusiasm for creating a national art aesthetic, did not concern themselves much with nationalism. Jackson helped the women establish their careers by promoting their work to collectors and curators and by offering technical advice. While the most recent exhibition lauds Jackson's patronage, feminist art historian Barbara Meadowcroft claims that he could also be patronizing. ${ }^{26}$ Evelyn Walters, however, suggests that Jackson encouraged the women to abandon the "schoolisms" of the art world establishment. ${ }^{27}$ The dictum "To thine own self be true," consistent with Modern Girl ideals of self-discovery, independence, and personal expression, was at the heart of the Beaver Hall women's view of art - a departure from the aesthetic of the Group of Seven and its connection between nationalism and wilderness. The Beaver Hall women combined modernism characterized by a distinctive use of broad brushstrokes of vivid colour in artistic landscapes with the francophone tradition in landscape art that included habitants or signs of civilization such as buildings and tools. ${ }^{28}$ Sarah Robertson, Kathleen Morris, and Ethel Seath all painted canvases in the 1920s that used the rural landscape to evoke what art historian Esther Trépanier described as "a form of modern regionalism." ${ }^{2}$

The Beaver Hall women engaged with the modernity of their urban milieu that was constitutive of the new visibility of the Modern Girl of the 1920s and marked by the presence of young immigrant wage-earning women in their representations of women on canvas. This was evident in the portraiture and urban landscapes by the group. They painted women from all walks of life and from different ethnic and racial backgrounds. Prudence Heward's The Immigrants received mixed reviews from art 


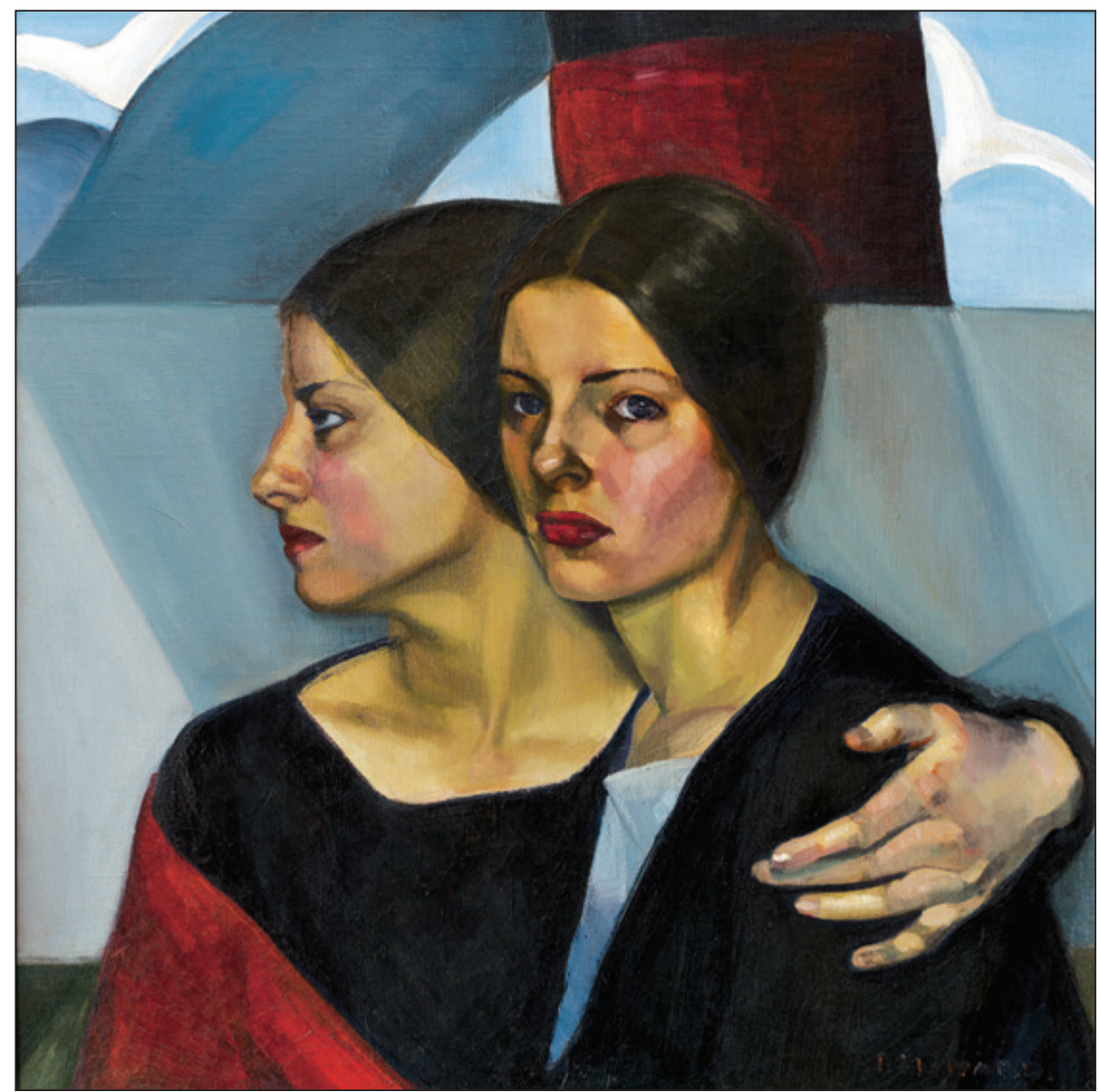

Figure 1: Prudence Heward (Canadian, 1896-1947). The Immigrants. 1928. Oil on canvas. $66 \times 66 \mathrm{~cm}$. Toronto, private collection. Courtesy of Montreal Museum of Fine Arts.

critics when it was first exhibited in 1921 for the muscular frame and use of powerful colour contrasts in tones of yellow, blue, and green: a welcome contrast to the pallid colour traditionally used in representations of women, according to one critic. ${ }^{30}$

Mabel May's Indian Woman, Oka (1927), conveys Indigenous women's dignity and strength with its use of bright colour against a natural backdrop. ${ }^{31}$ Some of the essays by the members of the Modern Girl Around the World Research Group suggest that ideas about race and skin colour became entangled in a process of racial hybridity as discussions about desirable skin colour contributed to the reworking of social hierarchies and racial formations. Uta Poiger suggests that images of the Modern Girl circulated globally in a "cosmopolitan aesthetic" in "conversation with changing ideas about colonial relations, race, and nationalism." ${ }^{32}$ This global circulation of images of the Modern Girl in "multidirectional citation" might be applied to works of the women artists of the Beaver Hall Group. They were influenced by the Impressionists and French modernists in their use of colour and form and used these 
ideas to represent the modern female body. Prudence Heward, perhaps the most wellknown female member of the group, learned about the trends in European modernism while working for the Red Cross in London during the First World War and after the war took classes in Paris from post-Impressionist artist Charles Guerin. ${ }^{33} \mathrm{~A}$ "cosmopolitan aesthetic," was evident in the landscapes and portraiture of the Beaver Hall women. May's Indigenous woman does not appear as an anti-modern relic or in stereotypical costume, and her skin colour is a dark bronze tone with vivid red lips. As Nicholas points out, one of the striking features of the Canadian Modern Girl was her "whiteness," and Heward's immigrant women and May's Indigenous woman are coded with some of these characteristics. ${ }^{34}$

Even in the rural landscapes, artists of both sexes represented women as modern women characterized by their direct gaze, fashionable clothes with attention to modern fabrics, modern hairstyles, and use of makeup. ${ }^{35}$ Prudence Heward has been praised by feminist art historians for her depictions of "striking individuality that is underscored by the imposing scale of their bodies and the often muted but contrasting tone of their skin." ${ }^{36}$ Heward's nudes, notably her 1931 canvas, Girl Under a Tree, represents the clash of styles characteristic of the Beaver Hall Group, with a larger-than-life musculature and confident sexuality that foregrounds a muted, flat, and simplified abstract landscape.

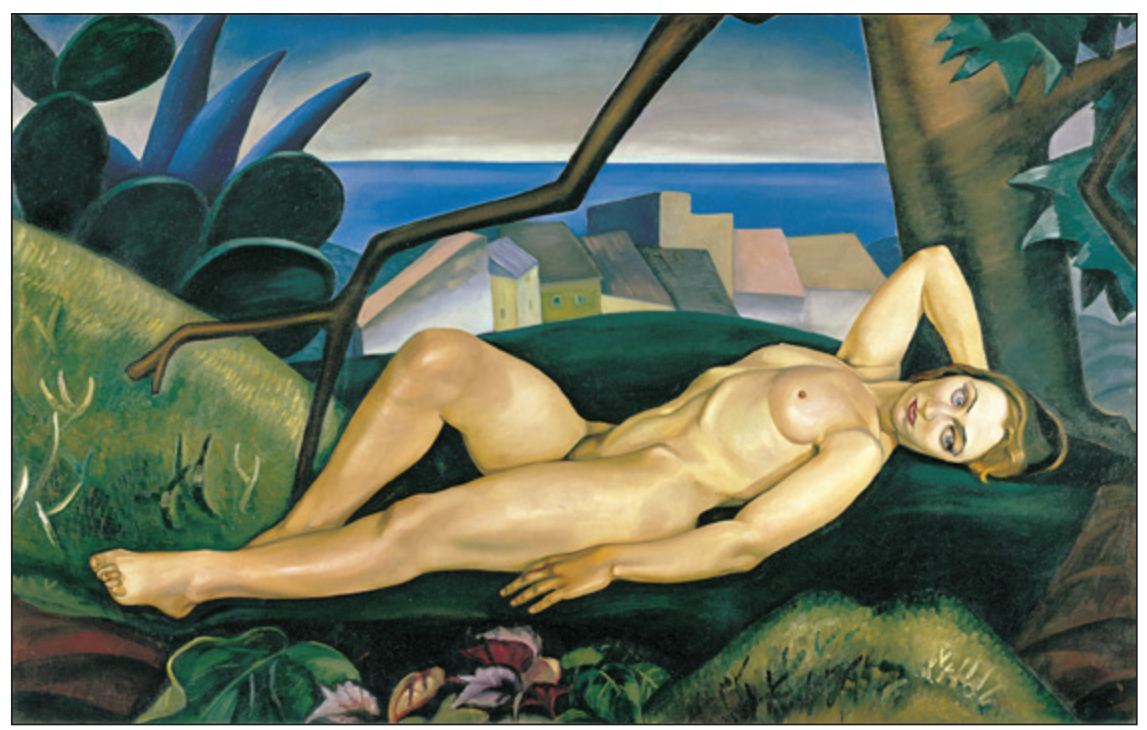

Figure 2: Prudence Heward. Girl under a Tree. 1931. Oil on canvas. $122.5 \times 193.7 \mathrm{~cm}$. Courtesy of Art Gallery of Hamilton, gift of the artist's family, 1961.

This painting generated criticism when it was shown as part of the Group of Seven exhibition in December 1931. As Pepita Ferrari writes: "The truth was that the pose was considered too provocative and, worse still, the nude was painted by a woman, [and] female nudes were then considered the exclusive territory of the male artist." ${ }^{\prime 3}$ 
Still, the reaction was mild in comparison to that which occurred four years later, in November 1933, when the Art Gallery of Toronto refused to hang Lilias Torrance Newton's Nude in a Studio (1933), claiming that the open-toed green sandals worn by the model and her garish red nail polish rendered her offensively naked. ${ }^{38}$ Interestingly, the nudes painted by the Beaver Hall women generated criticism not merely because they were painted by women, but because they painted nudes of Modern Girls, emphasizing their close proximity to consumer goods associated with the flapper, like makeup and fashionable shoes. ${ }^{39}$

The Beaver Hall women demonstrate why the flapper matters, and why she should continue to matter to Canadian women's history and historiography. They were autonomous historical actors who indulged in new forms of feminine consumption, they created a new modern art in Canada with their representations of the Modern Girl, and they challenged the gender binaries surrounding the ideology of separate spheres. Their close-knit network of women's friendships defied male dominance in the Canadian art profession and allowed them to carve out successful professional careers. Their use of colour and texture and scale and symbolism in their landscapes and in their portraits of women from all classes and ethnic and racial backgrounds contributed to the development of a new, more diverse, visual culture based on a strong, independent, assertive Canadian feminine modernity. Thus, an analysis of visual culture using Canadian women's art is important to the study of women's history in Canada. Recent historical writing surrounding the Modern Girl and the women artists of the Beaver Hall Group challenges the gender binaries that still dominate the writing of Canadian history. The representations of Modern Girls created by the women of the Beaver Hall Group offer students important critical tools for engaging with images and social and cultural issues. Furthermore, many of us teach large undergraduate women's history classes with students who are exposed to a barrage of hypersexualized, sexist, and pornographic images of young girls and women in social media accompanied by demeaning comments. ${ }^{40}$ The art of the Beaver Hall Group has considerable potential for teaching visual culture and possibilities for demonstrating to students that there are images of women that are empowering. The women of the Beaver Hall Group also offer students the opportunity to engage with actual historical flappers and consider how this group of women artists confronted modernity in 1920s Montreal. For these reasons I decided to incorporate a tour of the exhibition into the course for the fall 2016 semester.

\section{Introducing the Art of the Beaver Hall Group to University Students}

On August 10, 2016, I toured the Beaver Hall exhibition with Christina Simmons and Bruce Tucker, former colleagues in the history department. We agreed that the exhibit had potential for engaging undergraduate history students in visual literacy, modernity, the Modern Girl, and Canadian modern art. Our concern, however, was that it might be difficult for students to understand how and why the women of Beaver Hall were significant to the development of Canadian modern art in the 1920 s and to the visual representation of the Modern Girl in particular. Students 
who had little or no knowledge of the earlier development of portraiture and landscape art in Canada would likely find it difficult to comprehend how the work of the Beaver Hall Group was transformative.

The following day, I met with Jaclyn Meloche, the curator of contemporary art at the Art Gallery of Windsor, and Jessica Cook, the education and public programs coordinator. We arranged a tour for the class for September 28-earlier in the semester than I would have liked, since students would not yet have been exposed to much of the scholarly literature on the Modern Girl, but necessary, given that this was the last date possible for the class to visit before the exhibition closed. I raised the concern about students' knowledge of Canadian art history, and Meloche agreed to deliver a background lecture the week before the class was scheduled to visit the gallery. Although we had only one seminar before her lecture, I introduced the flapper to the class as representation and historical actor. I had the class read the introduction to the collection of essays written by the Modern Girl Around the World Research Group and we discussed the simultaneous emergence of the Modern Girl globally. By putting the Modern Girl at the centre of study as a heuristic device, we could study various facets of feminine modernity, including consumption, visual culture, commodities, and nationalism. ${ }^{41}$

Meloche, a self-identified feminist with an interdisciplinary $\mathrm{PhD}$ in the humanities - visual arts, performance studies, art history, and communication studies - proved an ideal fit for the course. She came to the campus and presented the class, comprised of three history majors and two concurrent history-English majors, with an overview of pre-1920s Canadian art history, emphasizing the role of the woman artist in Canadian society at the time and the constraints upon them, so that the students might understand more fully upon viewing the exhibition how the representations of the Modern Girl by the Beaver Hall Group and the women artists as real Modern Girls transformed Canadian art. Meloche pointed out that before the 1900s women had limited access to subjects and their paintings focussed on botanical matter. The nude body was the exclusive purview of male artists. It was only women with upper-class status and privileges who had access to art training, where they copied the work of men to hone their technique. It was not until the 1870s that art was a subject that elite women might learn in private schools. Meloche stated: "An awareness of the cultural, social and political climate of the Canadian art world prior to the formation of the group is important for these conditions inevitably informed many choices being made amongst the group's members." 42 She concluded her lecture by setting the stage for the tour of the exhibit scheduled for the following week, suggesting that "through the paintings and sculptures in the exhibition we... begin to learn more about the status and role of the gendered body at a time when women were slowly experiencing emancipation." ${ }^{43}$ I completed the seminar for the week with a screening of Pepita Ferrari's documentary By Woman's Hand, which focussed on the life and art of Prudence Heward and two of her fellow painters, Anne Savage and Sarah Robertson. The film emphasizes women's activism in the male-dominated art world through their informal friendship networks, and we discussed connections to the Modern Girl. ${ }^{44}$ 
The following week Meloche conducted a two-hour tour of the Beaver Hall exhibit. The class was given a brief writing assignment to encourage them to think about the Beaver Hall Group alongside the formulation of the Modern Girl by historians. I asked the students to write a four- to five-page critical paper explaining how the Modern Girl was represented in the paintings of the women artists of the Beaver Hall Group with attention to the significance of the women in the development of Canadian modern art and how these artists fashioned their own identities as modern women. Meloche was informed of the assignment beforehand and provided the students with insightful comments about the Beaver Hall women as embodiments of modern womanhood and she offered suggestions as to why the flapper matters to Canadian art history. Later, as the semester came to a close, I asked the students in the seminar, plus a history graduate student who came along on the tour, to provide by email any additional comments they might have about the art of the Beaver Hall women, feminism, visual culture, and Canadian history. These comments provided me with valuable insights into the connections students were making between their experiences in other university-level history courses, women's history, the flapper, the making of the modern body, and social media.

Meloche began the tour with the section of the exhibition devoted to the portraiture of the Beaver Hall Group. She spoke in detail about Lilas Torrance Newton's 1929 self-portrait, making connections to the Modern Girl.

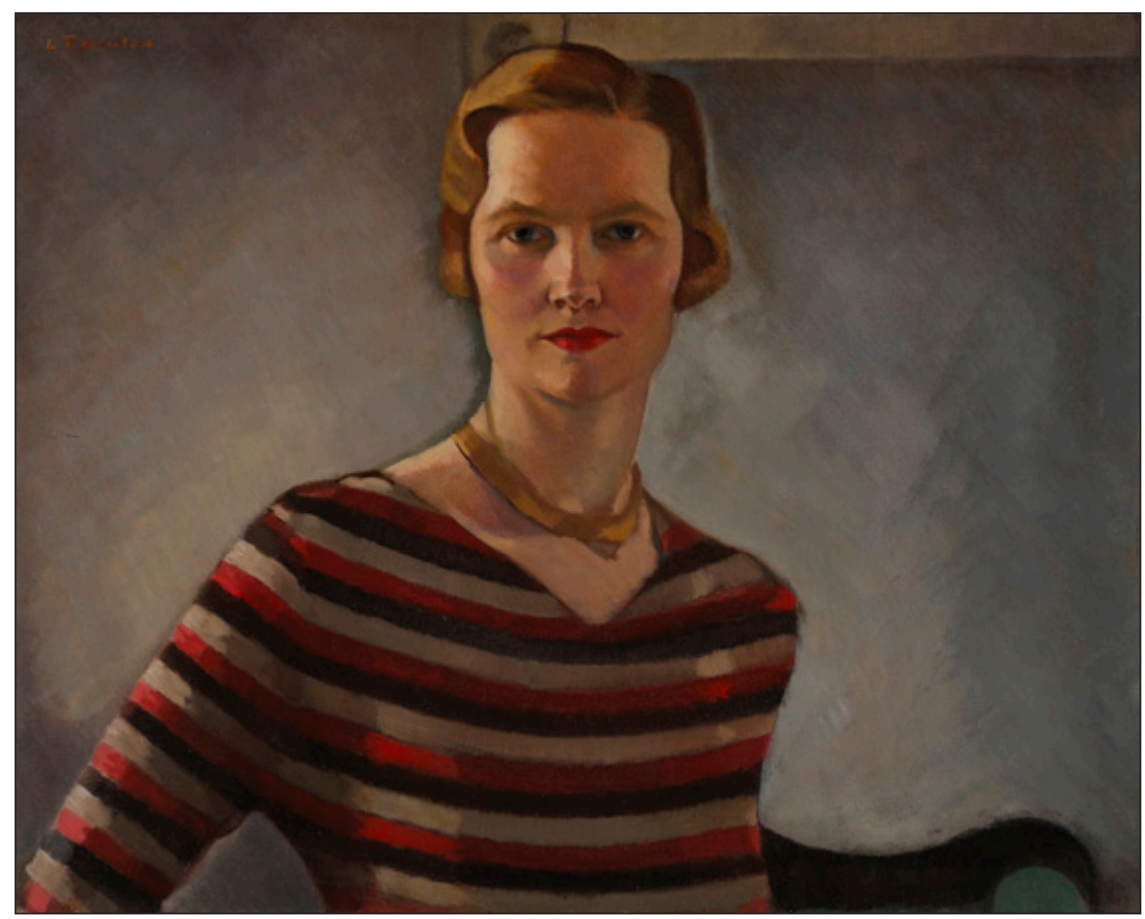

Figure 3: Lilias Torrance Newton. Self-portrait. ca. 1929. Oil on canvas. $61.5 \times 76.7 \mathrm{~cm}$. Courtesy of National Gallery of Canada, Ottawa. 
Newton was in her early thirties when she completed the self-portrait. As Meloche explained, the canvas is illustrative of the new public space occupied by women, and Newton clearly took on aspects of the Modern Girl style and consumed Modern Girl commodities. Her blonde hair is cut into a fashionable bob, she is wearing makeup, most evident in the vivid red lip colour, and a striped V-neck sweater, and her shoulders are pulled back as she gazes directly ahead. She possesses the Modern Girl look, and as a professional artist she is the embodiment of a modern professional woman. "Through the representation of makeup, clothing, posture and the gaze," Meloche commented, "women artists were changing the ways in which women were being portrayed in portraiture." 45 The women artists honed their technique by painting portraits of one another and they formed lifelong support networks of women's friendship and activism as they sought inclusion in the male-dominated art world.

Newton's self-portrait resonated with students in ways that the conventional lecture in Canadian women's history had not. One student wrote,

One thing I found that was particularly interesting to me was the distinction between how men viewed women and how women viewed women. Paintings of women by women tended to illustrate more strength, confidence, and emotion. This definitely ties in to ideas of feminism and themes of companionship between women. Work that paints women with integrity rather than weakness helps to promote gender equality in ways that weren't often seen during this time. Combined with the fact that the Beaver Hall Group consisted of both men and women working together, this exhibit exemplifies how the modern girl was becoming part of the social sphere and gradually becoming more of an equal to her male counterparts. ${ }^{46}$

Another student remarked, "These portraits, such as the Newton self-portrait... were definitely my favourites of the collection, as they produced the image of strong, feminine women, that to be perfectly honest, I had never associated with the early twentieth century." "While I had learned from previous history classes that first wave feminism occurred," she continued, "I had never heard of any feminist activity after women were given the vote until the 1960s, though it seems obvious now that women would have still fought for equal rights." ${ }^{7}$ For this student, the portraits posed a significant challenge to the male gaze and expressed something powerful about women: "I felt each portrait done by the women of Beaver Hall were [sic] looking directly at me, almost as if they were daring me to judge them." 48

Meloche and I agreed that we wanted to use the visual culture of the Beaver Hall Group to encourage students to move outside dominant patriarchal views of women as sexual objects of men's desire and understand the women of Beaver Hall as historical subjects who identified with the Modern Girl and represented her in their art. This idea was given a place of prominence in the exhibition itself in a panel entitled, "The Nude: New Canons of Feminine Beauty." As stated in the panel, "the freedom enjoyed by some artists, such as Heward, in their depictions of the increasingly free feminine body — long an object of censure — demonstrates how the body as subject 
can serve as a barometer of modernism." Meloche clearly distinguished between the use of "naked" and "nude" for the students, who for the most part, were unfamiliar with the conventions of art history. Male artists' paintings of "naked" women suggest vulnerability, whereas the paintings of "nude" women by the Beaver Hall Group point to the empowerment of modern women. Prudence Heward's Girl Under a Tree, completed in 1931, presents a sensual yet powerful, strong, larger-than-life nude woman's body using bold lines, a straight ahead gaze, and the trademark bright red lips of the Modern Girl. ${ }^{49}$

The nudes by the Beaver Hall Group, particularly those by Prudence Heward, encouraged students to think about representations of the female body in art. One student wrote: "The use of nudity was incredible too; I loved how the nudity was so natural and powerful versus being sexual." ${ }^{0}$ Students also made comparisons between the strong, liberated, feminine modern women in the art of the Beaver Hall Group and contemporary activism in social media. Another student linked Heward's nude with the "Free the Nipple" campaign organized around the release of Lina Esco's 2012 film of the same title. The campaign, now a social media phenomenon, has evolved into something more "than women going topless," and presently exists as a global movement "to raise awareness, and affect change, in the areas of the inequality of men and women that are still being experienced in the world today." ${ }^{1}$ This student wrote:

On social media there is the "Free the Nipple" campaign which is about an aspect of the female body that is often sexualized and taking away the sexual connotations. This is a hot topic today and this campaign is often criticized but these women managed to show the female form without making her a sex object. Instead, we saw power, strength as well as a sense of beauty without objectifying the subject. These women managed to show the female body in a way that our modern society can't. ${ }^{52}$

Her comments suggest that the images of women's bodies painted by the women in the Beaver Hall Group matter today. They encourage students to see women and their bodies as something other than sexual objects.

As we passed through the section of the exhibit called the "The Jazz Wall," it was obvious why early twentieth-century conservative critic Hector Charlesworth described the Beaver Hall Group as the "hit-em-in-the-eye" school, with the bright colours in the canvases and associations with the 1920s jazz scene in Montreal. This section of the exhibition even included replications of art deco furniture of the era. Meloche discussed changes in the social life of the city after the First World War, where women of all classes and ethnicities frequented bars, clubs, and cocktail parties. At the centre of the room were three bronze sculptures by a male artist in the group, Henri Hébert: Dancer at Rest (1926), Flapper (1927), and Charleston (1927). "The dancer's nudity," exhibition co-curator Brian Foss writes, served to "heighten her physical strength and grace, and a clear sense of personality is conveyed by means of individualized facial features." 53 Theatre was a prominent commercial entertainment 


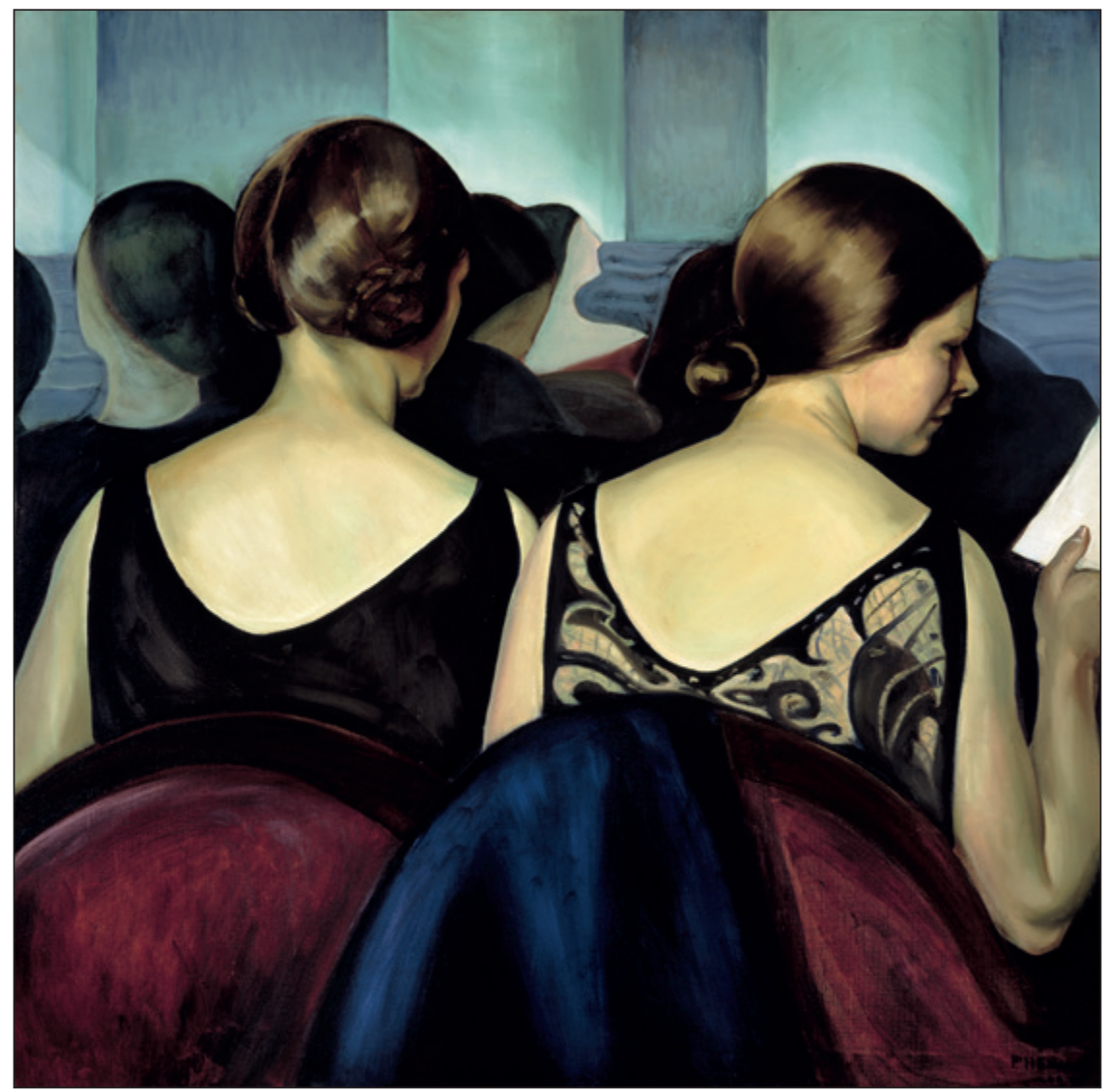

Figure 4: Prudence Heward. At the Theatre. 1928. Oil on canvas. $101.6 \times 101.6 \mathrm{~cm}$. Horsley and Annie Townsend bequest, 1963. Courtesy of Montreal Museum of Fine Arts.

in 1920s Montreal. Prudence Heward's 1928 canvas At the Theatre appeared in a prominent place on "The Jazz Wall."

Two women are represented from the back, in fashionable backless dresses, and against the abstract bodies of the audience. The women are at the theatre without chaperones, which speaks to the more independent position women were assuming in public at the time. Similarly, art historian Barbara Meadowcroft suggests that the piece "best conveys the spirit of the Beaver Hall painters":

This image of women enjoying a performance together is a celebration of women's friendship. And since the models were Sarah Robertson's sisters, the reference to the Beaver Hall Painters is clear. At the Theatre is an evocation of the affection, shared goals, and passion for painting that united these painting friends. ${ }^{54}$ 
Furthermore, one student described the "scantily dressed" women in the canvas as showcasing post-war changes in fashion towards the Modern Girl style and women's engagement with consumer culture. ${ }^{55}$

The portraits on "The Jazz Wall" allowed the students in the class to apply the tools of feminist intersectional analysis. Working-class women and immigrant women were represented in the group's portraiture. One student was particularly struck by the expression of the women in Heward's The Immigrants. She writes that "the two women are presented as close (familial maybe), terrified and morbid all at the same time," and she was struck by the ethnic and class diversity in Heward's paintings. She further remarked: "What was also surprising to me was the diversity of Prudence Heward's works as most art that I knew of features only white women." 56

For students, the landscapes painted by the Beaver Hall Group were a significant contrast to the canvases of the Group of Seven for whom modernism and Canadian identity were tied to masculine ideals of the wilderness and the North. While Lawren Harris of the Group of Seven created many colourful canvases of Toronto houses, art historian Esther Trépanier argues that he did not display the same kind of relationship to urban space as those painted by the Beaver Hall women. For the most part, the landscapes of these women feature neighbourhoods in Montreal's west end, where they lived their daily lives. Meloche pointed out that the women of Beaver Hall painted from interior spaces through a window, as in Sarah Robertson's study for In the Nun's Garden (1932), whereas the men painted the busy streets of urban Montreal from the exterior at street level..$^{57}$ Students commented on the contrast between the "empty landscapes" of the Group of Seven in comparison to the vibrant representations of women in residential neighbourhoods, and in the town and farms of rural Quebec, all demonstrating, according to one student, the "strength, confidence, and emotion" of the women..$^{58}$

Canadian modern art contributes significantly to the historical study of the Modern Girl and allows students and researchers to unpack the idea of why the flapper still matters. Overall student response to the Beaver Hall exhibit was positive. One student remarked that the exhibit was "eye-opening" for her as a history student: "Art is something that I never would have thought of using as a primary source, although I now see that it can be extremely useful for seeing cultural and social ideas in unique ways." She continued, "I'm glad that I had the opportunity to visit this exhibit because I likely never would have gone otherwise," thus reinforcing the importance of experiential learning for undergraduates. ${ }^{59}$ For students interested in feminism, women's history, and visual culture, images and life experiences of Canadian women artists challenge the traditional narrative of Canadian history students are still taught as undergraduates. As the students in the seminar discovered, "history is so much more than reading it through a textbook, and seeing the radical changes in feminism and women's art on canvas was a real delight." ${ }^{60}$ Another student commented on the neglect of women artists in her previous history courses: "I feel cheated with my education because I was limited to only the Group of Seven, not to diminish their contribution to the art world but the Beaver Hall Group was just as important." ${ }^{\prime 1}$ 


\section{Conclusion}

I undertook this article as work in feminist self-reflection and to discuss the flapper as a historical, historiographical, and pedagogical problem. The flapper opens up possibilities to study changeable feminine bodies and to break down the long-standing opposition between subject and object surrounding the history of women in Canada and in Canadian historical writing. The women artists in the Beaver Hall Group fostered a new modern art in Canada in the 1920s around the Modern Girl aesthetic, and they took on aspects of the Modern Girl look in constituting themselves as artists and professional women.

The Beaver Hall exhibition introduced experiential learning into the course and brought students into the Art Gallery of Windsor. Through the Beaver Hall exhibit, students were able to use feminist art history as a critical tool for engaging with visual culture alongside the scholarship by the Modern Girl Around the World Research Group to think about how feminine modernities intersect with race, sexuality, class, and nationalism, thereby reinforcing the importance of the flapper for history, historiography, and pedagogy. The expression of these ideas in the written form is something I still need to devote more attention to in the classroom, with more instruction in academic writing. Nevertheless, students were able to take the tools of visual cultural analysis and apply them in ways that challenged the sexualization and objectification of women in contemporary society, particularly in social media. Students also saw that women's friendships and networks of activism extended beyond suffrage into the 1920s and beyond. Significantly, for history and the writing of history the flapper still matters. The flapper allows us to recast the narrative of Canadian history and to discover the accomplishments of Canadian women, including the women artists who have for too long been cast under the shadow of the Group of Seven, our so-called national artists.

\section{Notes}

My thanks to Jaclyn Meloche, Christina Simmons, Bruce Tucker, Renée Bondy, Carol Reader, Leslie Howsam, Charlotte Parent, and Kelvin Leddy for their many useful comments. Special thanks to Jane Nicholas for sharing her insights about the flapper for the teaching and writing of history and for her unwavering support and good humour. Finally, my heartfelt appreciation to my students in the Modern Girl seminar for sharing their ideas and keeping me grounded in the contemporary world of modern women.

1 Alys Eve Weinbaum, Lynn M. Thomas, Priti Ramamurthy, Uta G. Poiger, Madeleine Yue Dong, and Tani E. Barlow, "The Modern Girl as Heuristic Device: Collaboration, Connective Comparison, Multidirectional Citation," in The Modern Girl Around the World: Consumption, Modernity, and Globalization, Alys Eve Weinbaum et al., eds. (Durham, NC: Duke University Press, 2008), 1-22; Liz Conor, The Spectacular Modern Woman: Feminine Visibility in the 1920s (Bloomington, IN: Indiana University Press, 2004), 209-52; Penny Tinkler and Cheryl Krasnick Warsh, "Feminine Modernity 
in Interwar Britain and North America: Corsets, Cars, and Cigarettes," Journal of Women's History 20, no. 3 (1998): 113-43; Jane Nicholas, The Modern Girl: Feminine Modernities, the Body, and Commodities in the 1920s (Toronto: University of Toronto Press, 2015), 3-11.

2 Weinbaum et al., "The Modern Girl as Heuristic Device," 9-10; Nicholas, The Modern Girl, 10.

3 Weinbaum et al., "The Modern Girl as Heuristic Device,", 1-22.

4 Ibid., 15-18.

5 Sarah Parsons, "Radical Possibilities: Feminism, Pedagogy and Visual Culture," Resources for Feminist Research 29, no. 3.4 (Fall 2002): 155-66; Carmen Luke, "Feminist Pedagogy and Critical Media Literacy," Journal of Communication Inquiry 18, no. 2 (Summer 1994): 30-47; Lynne M. Webb, Myria W. Allen, Kandi L. Walker, "Feminist Pedagogy: Identifying Basic Principles,” Academic Exchange (Spring 2002): 67-72; Tracy Penny Light, "I Can't Believe I've Never Seen That Before!: Feminism, the Sexualization of Culture, and Empowerment in the Classroom," in Feminist Pedagogy in Higher Education: Critical Theory and Practice, ed. Tracy Penny Light, Jane Nicholas, and Renée Bondy (Waterloo, ON: Wilfrid Laurier University Press, 2015), 279-91.

6 Veronica Strong-Boag, The New Day Recalled: Lives of Girls and Women in EnglishCanada, 1919-1939 (Toronto: Copp Clark Pitman, 1988); Carolyn Strange, Toronto's Girl Problem: The Perils and Pleasures of the City, 1880-1930 (Toronto: University of Toronto Press, 1995).

7 Jane Nicholas, The Modern Girl; Cheryl Krasnick Warsh and Dan Malleck, eds., Consuming Modernity: Gendered Behaviour and Consumerism Before the Baby Boom (Vancouver: UBC Press, 2013); Tamara Myers, Caught: Montreal's Modern Girls and the Law, 1969-1945 (Toronto: University of Toronto Press, 2006).

8 See Bonnie G. Smith, The Gender of History: Men, Women, and Historical Practice (Cambridge, MA: Harvard University Press, 1998), 214-40, for a discussion of the historiographical debates in the interwar period surrounding historical modernity and femininity, and gendered criticisms surrounding women in the historical profession.

9 Carolyn Steedman, "La Théorie qui n'en est pas une; or, Why Clio Doesn't Care," in Feminist Revision History, ed. Ann-Louise Shapiro, (New Brunswick, NJ: Rutgers University Press, 1994), 73-94; Smith, The Gender of History.

10 For a discussion of the mannequin in the modern commodity scene, see Conor, The Spectacular Modern Woman, 105-28; Katherine H. Adams, Michael L. Keene and Jennifer C. Koella, Seeing the American Woman, 1880-1920: The Social Impact of the Media Explosion (Jefferson NC, and London: McFarland \& Company, 2012), 67-77.

11 Steedman, "Why Clio Doesn't Care," 83.

12 See Zoe Heller, "'Hot' Sex \& Young Girls,” New York Review of Books, August 18, 2016.

13 Renée Bondy, Jane Nicholas, and Tracy Penny Light, "Introduction: Feminist Pedagogy in Higher Education, " in Bondy, Nicholas, and Light, Feminist Pedagogy in Higher Education, 3.

14 Karen Stanworth, "Revisioning the 'Culture of Nature' in Canadian Visual Culture Studies: John Russell and An/Other Case of Modern Art," Journal of Canadian Studies 47, no. 3 (Fall 2013): 67-70; Brenda Lafleur, " 'Resting' in History: Translating the Art of Jin-me Yoon," in Griselda Pollock, Generations and Geographies in the Visual Arts: Feminist Readings (London and New York: Routledge, 1996), 217-27.

15 See http://www.ago.net/the-idea-of-north-the-paintings-of-lawren-harris, accessed August 21, 2016.

16 Sandra Alfoldy, Crafting Identity: The Development of Professional Fine Craft in Canada (Montreal: McGill-Queen's University Press, 2005), 96-105. 
17 Barbara Meadowcroft, Painting Friends: The Beaver Hall Women Painters (Montreal: Véhicule Press, 1999); Evelyn Walters, The Women of Beaver Hall: Canadian Modernist Painters (Toronto: Dundurn Press, 2005); Pepita Ferrari, By Woman's Hand, National Film Board of Canada, 1994.

18 Jacques Des Rochers, "The Beaver Hall Group: A Much Anticipated Re-Reading," in 1920s Modernism in Montreal: The Beaver Hall Group, ed. Jacques Des Rochers and Brian Foss (London: Black Dog Publishing, 2016), 27.

19 Nathalie Bondil, “The 'Hit-em-in-the-Eye' School, or Painters of 'Wall Jazz'”, in Des Rochers and Foss, 1920s Modernism in Montreal, 25.

20 Nicholas, The Modern Girl, 4-11.

21 Meadowcroft, Painting Friends, 35-36, 53; Des Rochers and Foss, 1920s Modernism in Montreal, 295.

22 Maria Tippett, By a Lady: Celebrating Three Centuries of Art by Canadian Women (Toronto: Viking, 1992), 61-109.

23 Kristina Huneault, “'As Well as Men': The Gendering of Beaver Hall," in Des Rochers and Foss, 1920s Modernism in Montreal, 265.

24 Weinbaum et al., The Modern Girl Around the World, 9-10.

25 In the introduction to their collection of essays that addresses "separate spheres" in the writing of the history of nineteenth century Maritimes women, editors Janet Guildford and Suzanne Morton point out that the ideology of separate spheres was never a reality since both working-class and middle-class women moved between the public sphere of waged work, religion, and politics and the private sphere of the home and domesticity. They further state, however, that the ideology of separate spheres has had, and continues to have, "a powerful negative and constraining impact on women's lives," and continues to warrant the attention of women's historians. See Janet Guildford and Suzanne Morton, "Introduction," in Separate Spheres: Women's Worlds in the 19th Century Maritimes, ed. Janet Guildford and Suzanne Morton (Fredericton, NB: Acadiensis Press, 1994), 9-12.

26 Meadowcroft, Painting Friends, 53.

27 Walters, The Women of Beaver Hall, 17.

28 Ibid., 16.

29 Esther Trépanier, "The Beaver Hall Group: A Montreal Modernity," in Des Rochers and Foss, 1920s Modernism in Montreal," 162-63.

30 Des Rochers and Foss, 1920s Modernism in Montreal, 260.

31 Trépanier, "The Beaver Hall Group: A Montreal Modernity," in Des Rochers and Foss, 1920s Modernism in Montreal, 228.

32 Uta G. Poiger, " 'Fantasies of Universality?' Neue Frauen, Race and Nation in Weimar and Nazi Germany," in Weinbaum et al., The Modern Girl Around the World, 317-44.

See also The Modern Girl Around the World Research Group, "The Modern Girl Around the World: Cosmetics Advertising and the Politics of Race and Style," in Weinbaum et al., The Modern Girl Around the World, 49-52; Liz Conor, "Blackfella Missus Too Much Proud: Techniques of Appearing, Femininity, and Race in Australian Modernity," in Weinbaum et al., The Modern Girl Around the World, 220-39.

33 See https://www.aci-iac.ca/prudence-heward/biography, accessed April 24, 2017.

34 Nicholas, The Modern Girl, 117.

35 Trépanier, "The Beaver Hall Group," in Des Rochers and Foss, 1920s Modernism in Montreal, 228.

36 Ibid., 228, 232.

37 Pepita Ferrari, "Prudence Heward: Painting at Home," in Framing our Past: Canadian Women's History in the Twentieth Century, ed. Kate O'Rourke, Lorna R. McLean and Sharon A. Cook (Montreal: McGill-Queen’s University Press, 2001), 132. 
38 See http://www.klinkhoff.ca/canadian-artist/Lilias-Torrance-Newton, accessed January 24, 2016.

39 Weinbaum et al., "The Modern Girl as Heuristic Device," 18-20; Nicholas, The Modern Girl, 38-43.

40 Heller, " 'Hot' Sex \& Young Girls.”

41 Weinbaum et al., "The Modern Girl as Heuristic Device," 1-24.

42 Jaclyn Meloche, email message to author, November 19, 2016.

43 Ibid.

44 Ferrari, By Woman's Hand.

45 Ibid.

46 Samantha Regier, email message to author, November 16, 2016.

47 Bailey Talpas, email message to author, November 15, 2016.

48 Ibid.

49 Art historian Kristina Huneault states that there is nothing "concrete about whether Heward intended to offer a commentary on gender with Girl Under a Tree." See Kristina Huneault, “'As Well as Men': The Gendering of Beaver Hall,” in Des Rochers and Foss, 1920s Modernism in Montreal, 292.

50 Nicole Mulder, email message to author, November 10, 2016.

51 Freethenipple.com, accessed December 31, 2016.

52 Nicole Mulder, email message to author, November 10, 2016.

53 Brian Foss, "Out on the Town: Modernism Arts and Entertainment in Montreal, 192033," in Des Rochers and Foss, 1920s Modernism in Montreal, 145.

54 Meadowcroft, Painting Friends, 176; Jacques Des Rochers, "The Beaver Hall Group: A Much Anticipated Re-Reading," in Des Rochers and Foss, 1920s Modernism in Montreal, 27.

55 Adelaide Dycha, email message to author, November 14, 2016.

56 Bailey Talpas, email message to author, November 15, 2016.

57 Esther Trépanier, "The Beaver Hall Group: A Montreal Modernity," in Des Rochers and Foss, 1920s Modernism in Montreal, 192; Samantha Regier, email message to author, November 16, 2016.

58 Carol A. Reader, email message to author, November 17, 2016.

59 Samatha Regier, email message to author, November 16, 2016.

60 Adelaide Dycha, email message to author, November 15, 2016.

61 Nicole Mulder, email message to author, November 10, 2016. 
136 Historical Studies in Education/Revue d'histoire de l'éducation 